\title{
Product Placement in Cinema-Good Model or Irritative Advertising
}

\author{
Isidor Karadimov \\ Department of Media and Public Communication, University of National and World \\ Economy
}

\section{Продуктовото позициониране в киното - добър модел или дразнеща реклама \\ Исидор Карадимов}

Катедра „Медии и обществени комуникации“, Университет за национално и световно стопанство

\section{Author Note}

Isidor Karadimov (D) https://orcid.org/0000-0002-6190-2548

The author has no conflict of interest to disclose.

Correspondence concerning this article should be addressed to Isidor Karadimov, 1700 Sofia, Student Town, University of National and World Economy, Department of Media and Public Communication. Email: Isidor@isidorproduction.com

\section{Бележки за автора}

Исидор Карадимов (D) https://orcid.org/0000-0002-6190-2548

Няма конфликт на интереси.

Кореспонденцията, свързана с тази статия следва да бъде адресирана до Исидор Карадимов, София 1700, Студентски град, Университет зо национално и световно стопанство, катедра Медии и обществени комуникации. Email: Isidor@isidorproduction.com 


\begin{abstract}
Product placement is one of the forms of financing in cinema. This is a legal form for realizing hidden advertising. Adherence to strict rules when implementing a product in the final version of the film for advertising purposes is a good tool, both to fill the budget and purely plot. In American film production, product positioning is intended to add a few percent to the film's budget. In Bulgarian cinema, product positioning is used as the main source of funding for the creation of an independent film outside those funded by the National film center (NFC).

Keywords: cinema, product positioning, consumer behavior
\end{abstract}

\title{
Резюме
}

Продуктовото позициониране е една от формите за финансиране в киното. То е легална форма за реализиране на скрита реклама. Спазването на строги правила при внедряване на продукт в окончателния вариант на филма с цел реклама е добро средство, както за попълване на бюджет, така и чисто сюжетно. В американското кинопроизводство, продуктовото позициониране е с цел да се добавят няколко процента към бюджета на филма. В българското кино продуктовото позициониране се използва като основен източник на финансиране при създаване на независим филм, извън финансираните от Националния филмов център (НФЦ).

Ключови думи: кино, продуктово позициониране, потребителско поведение

ARTICLE INFO:

Original Article

Received: 15, 10.2021

Revised: 29, 10.2021

Accepted: 14, 11.2021 


\section{Продуктовото позициониране в киното - добър модел или дразнеща реклама \\ Въведение}

В бизнес модела на световното кино, което разглежда аудиовизуалния филм като изкуство, но също и като продукт, който може да бъде продаден, липсва спонсорство в чистата му форма. Дадена компания спонсорира филм, но срещу показване на лого в завършения продукт. Продуктовото позициониране е най-развито в САЩ. В България заради слабо представяне на голяма част от българските филми, компаниите не са склони лесно да станат спонсори на даден аудио-визуален продукт.

При анализа на пазара може да проследим нежеланието на българските компани да инвестират в филми.

По данни от Националния статистически институт (НСИ) в България през 2020 г има 70 кина, 60 от тях са стационарни, а 10 мултиплекси.

\section{Таблица 1}

Кина в България

\begin{tabular}{|l|r|r|r|r|}
\hline & $\mathbf{2 0 1 6}$ & $\mathbf{2 0 1 7}$ & $\mathbf{2 0 1 9}$ & $\mathbf{2 0 2 0}$ \\
\hline Кина - бр. & 59 & 68 & 74 & 70 \\
\hline Екрани & 220 & 226 & 237 & 215 \\
\hline Прожекции - бр. & 321842 & 356385 & 317418 & 162906 \\
\hline Посещения - хил. & 5548 & 5506 & 4582 & 1316 \\
\hline $\begin{array}{l}\text { Среден брой прожекции на едно кино - } \\
\text { бр. }\end{array}$ & 5454,9 & 5241,0 & 4289,4 & 2327,2 \\
\hline $\begin{array}{l}\text { Среден брой посетители на едно кино - } \\
\text { хил. }\end{array}$ & 94,0 & 81,0 & 61,9 & 18,8 \\
\hline $\begin{array}{l}\text { Среден брой посетители на една } \\
\text { прожекция - бр. }\end{array}$ & 17,2 & 15,4 & 14,4 & 8,1 \\
\hline
\end{tabular}

Бележка: Таблицата е направена по данни на НСИ

https://nsi.bg/bg/content/3621/\%D0\%BA\%D0\%B8\%D0\%BD\%D0\%B0

От таблица 1 се разкрива, че до 2019 г. в България има ръст на кина и екрани. На този фон обаче, се откроява осезаем спад при средния брой посетители в кината, както и среден брой зрители на прожекция. Този спад корелира с възхода на стрийминг платформите. От друга страна, филмите, които се дистрибутират в България, както ще се проследи по-нататък в текста от данните на Националния филмов център (НФЦ) за българския показ, са предимно на големите американски студия, липсват европейски и световни филми. Появилият се през последните месеци корейски феномен - сериалът Squid Game е продукция на Netlix и успя да стане най - успешния продукт на стрийминг 
платформата (Rozenblat 2021). Squid Game се превърна в любомото шоу на интернет. Само за една седмица след премиерата му от 17 септември в редица страни като САЩ, Великобритания и т.н. се превърна в сериал номер 1. Ако този сериал беше филм и бе предназначен за кината, шансът да има премиера в България би бил изключително малък. Липсата на разнообразие в българските кина ограничава зрителя в техния избор. Именно тази липса е една от причините днешният зрител да започва да проявява интерес към абонамент за стрийминг платформи и все по - малко да ходи на кино. За съжаление, българският кинопоказ беше тежко засегнат от коронакризата. Видно от таблица 1 може да се проследи резкият спад на потребление на кино в България за 2020 г. По - голямата част от приходите през 2020 са от първите месеци на година. В България не бяха предприети почти никакви мерки за подпомагане на българските кина. До края на 2020 г. въпреки пандемичната обстановка и неколкократните искания за държавни помощи от страна на кината, не бяха получени помощи. Кината бяха поставени в обща категория с дискотеките и нощните заведения. Имаше нелогични заповеди, които разрешаваха, но същевременно забраняваха достьпите до кино. Тези факти, както и отлаганията на хитовите премиери е причината за огромния спад за 2020г.

На този фон, трябва да се отбележи, че близо половината от посетителите на кинопрожекции са лица на възраст от 16 до 29 години. (Графика 1). Едва 4\% са посетителите на възраст над 65 години. По - малко от 24\% е посещаемостта на активното работещо население в трудоспособна възраст.

\section{Графика 1}

Посетители в кино залите по демографски показател (години)

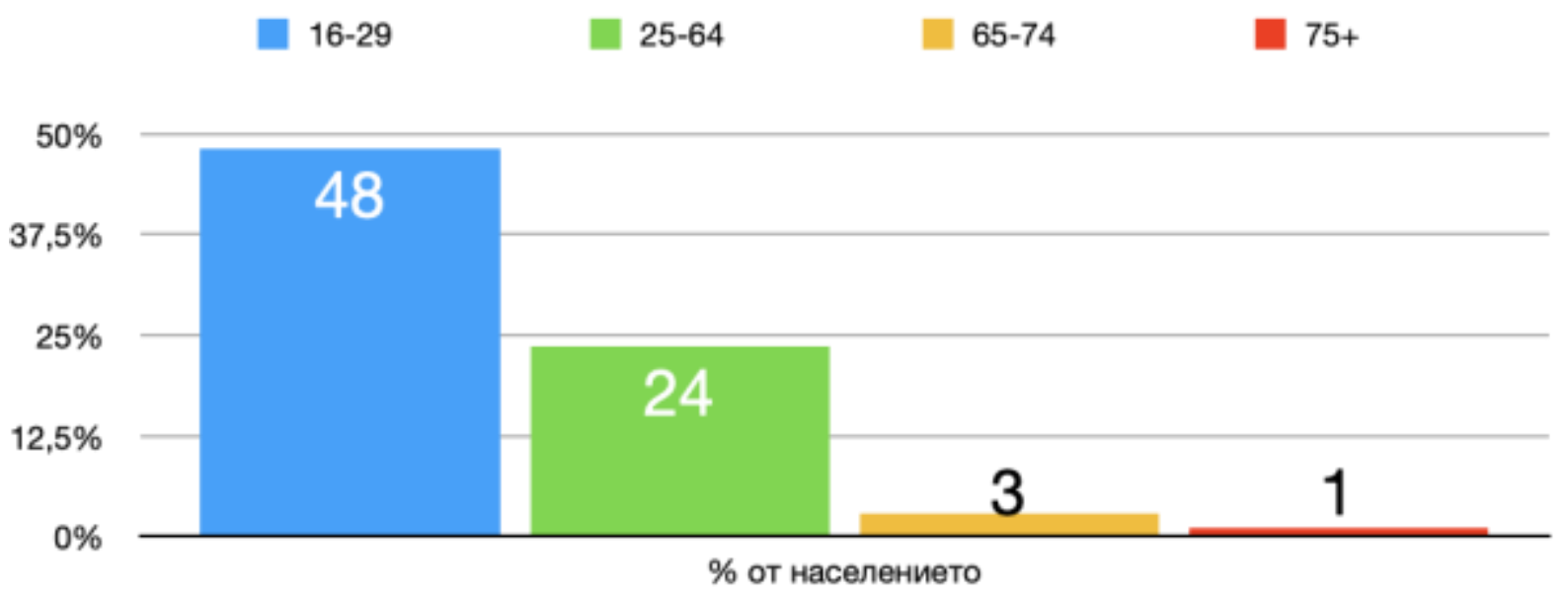

Бележка: Данните за България са от Евростат https://ec.europa.eu/eurostat/statisticsexplained/index.php?title=Culture_statistics_-_cultural_participation 
Цената на билетите в България е една от ниските, в сравнение с други държави в Европа. Средната цена на билет за кино е 3, 90 евро у нас. Под нея са цените в Турция и Хърватия. Цената на билет в сравнение с Европа е по-ниска, но поради по-ниската покупателна способност на българите, билетът се превръща в сравнително скъпо удоволствие.

\section{Графика 2}

Средна иена на билет за кино в избрани държави от Европа

Средна цена на билет за кино

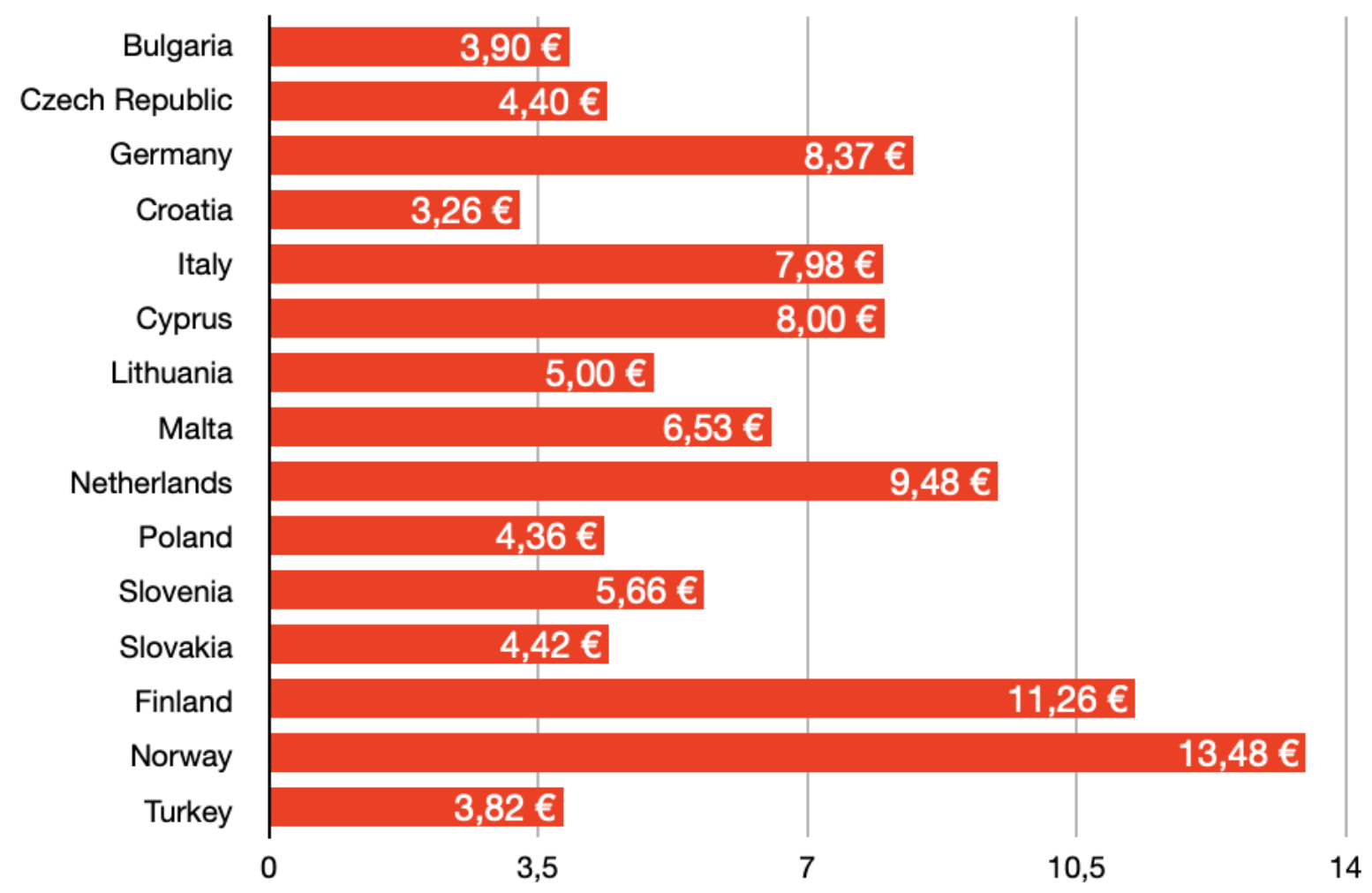

Бележка: Данните са за Европа от Евростат https://ec.europa.eu/eurostat/statistics-

explained/index.php?title=File:Cinema,_price_per_ticket_(in_euros),_2015.png\&oldid=302391

Посещаемостта е по - слаба в сравнение с останалите европейски страни.

Данните за най-предпочитаните български филми по критерия общи приходи от продажба на билети са отразени на Графика 3 (по данни на НФЦ за 2016г).

Най-касовият български филм с общи приходи от 718848 лв. за 2016г. се нарежда в топ 20 на най-гледаните филми у нас, излъчвани в българските кина, което говори за потребността от национални продукции, но и за изискванията на зрителите, които са 
предпочели“Ледена епоха” с общи приходи у нас в размер на 2501126 лв. Огромна е дистанцията по приходи мужду най-касовия и филма на последно място в топ 20 по приходи. Близо 700 пъти е разликата в приходите за първия и последния в класацията.

\section{Графика 3}

Вох Office на 2016 за издадени български филми с премиера през 20162.

indmissions

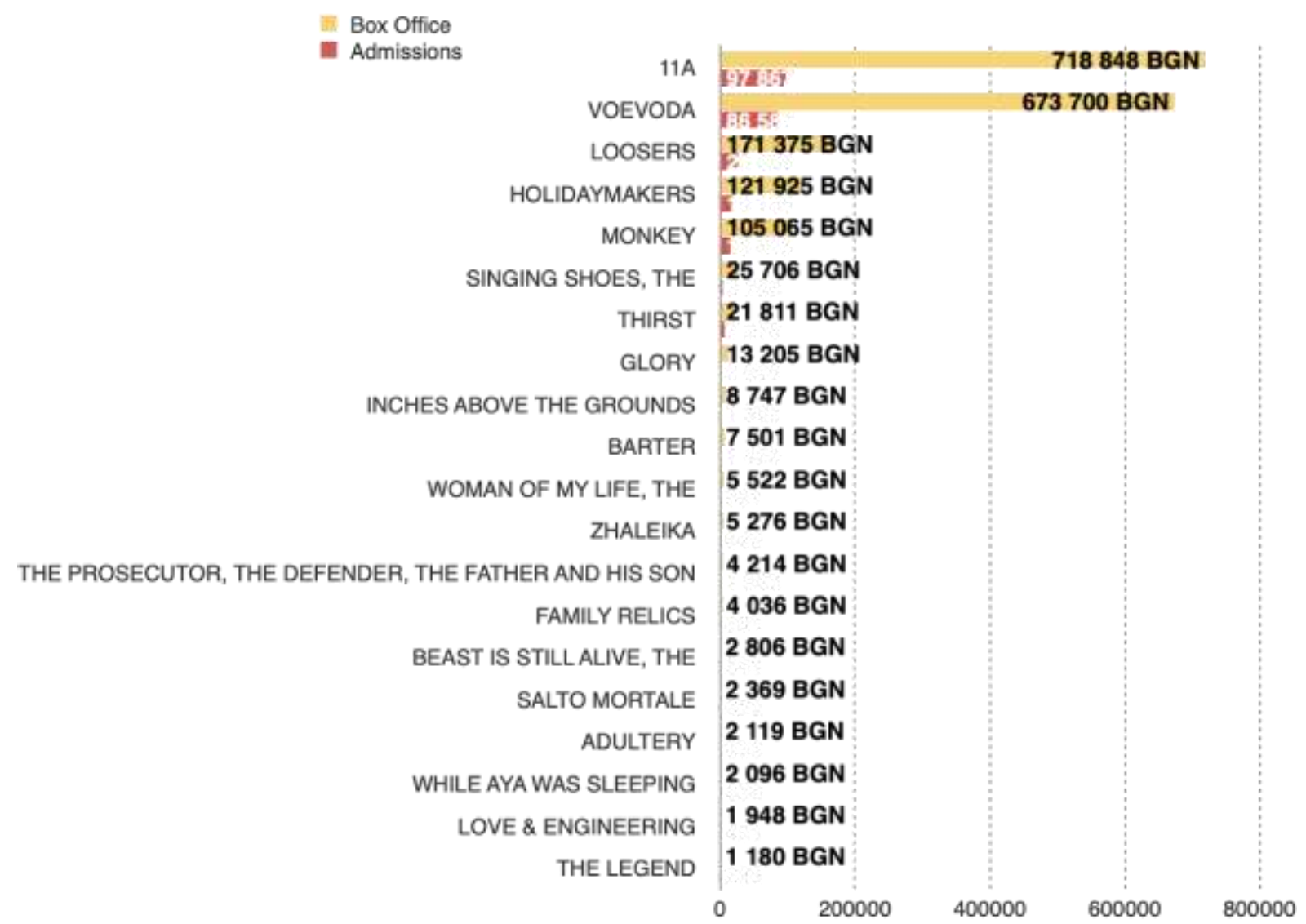

Бележка: Данните са за България от НФЦ за 2016 https://www.nfc.bg/статистика-публиченрегистьр/box-office/

Данните за 2016г. са избрани като конкретен период, защото тази година е много слаба за българското кино, независимо, че НФЦ е отпуснал големи суми за кинопроизводство. Всички филми от графика 3 са представени и излъчени в българските кина. 2016г. може да служи за пример, как не трябва да се правят български филми. Всъщност от Таблица 2 се проследява как българските филми се представят през следващите години - от 2016 до 2020 година. 


\section{Таблица 2}

Приходи от български филми показани в български кина 2016-2020

\begin{tabular}{|c|c|c|}
\hline Година & Брой зрители & Бруто приходи с ДДС \\
\hline 2020 & 136974 & 1166926 \\
\hline 2019 & 448777 & 3728676 \\
\hline 2018 & 388006 & 3065306 \\
\hline 2017 & 512889 & 4023682 \\
\hline 2016 & 177647 & 1193202 \\
\hline
\end{tabular}

Бележка: Данните са от НФЦ https://www.nfc.bg/статистика-публичен-регистър/box-office/

Общият бокс офис, който включва български и чуждестранни филми може да се проследи от таблица 3.

\section{Таблица 3}

Приходи от български и чуждестранни филми показани в български кина 2016-2020

\begin{tabular}{|c|c|c|}
\hline Година & Брой зрители & Бруто приходи с ДДС \\
\hline 2020 & 1337951 & 12685191 \\
\hline 2019 & 5016079 & 49009520 \\
\hline 2018 & 4900408 & 46036035 \\
\hline 2017 & 5573812 & 50700402 \\
\hline 2016 & 5532490 & 48424171 \\
\hline
\end{tabular}

Бележка: Данните са за България от НФЦ https://www.nfc.bg/статистика-публиченрегистьр/box-office/

Вниквайки в данните от таблицата за общ бокс офис за 2016г. се констатира, че тя е една от силните годни за кината в България, назависимо, че зрителите не са потребили българското кино. От 2017г. до 2020г. се разкрива корелация на данните при българските и при чуждестранните филми. Данните показват, че зрителят посещава киносалоните почти един и същ брой пъти през годинити, но когато не се представени интресни български заглавия, потребителят предпочита чуждоезичните филми. 2016г. е едновременно много ярък пример за много слаба посещаемост на българско кино и много силна за световно дистрибутирани филми. Въз основа на тези констатации, 2016 г. е научен интерс за разглеждане в настоящата разработка.

Едни от най-предпочитаните по вид филми в България са анимационните. Заключението произтича от данните от Графика 4. Челните три позиции по приходи за 
2016 г. по данни на НФЦ, са заети от анимационни филми с общи приходи от 5931733 лв. У нас 15 от филмите в топ 20 за 2016 г. са на 3D. Всъщност вкусът на българския зрител не се различава значително от американския. Най - касовият филм за 2016 г. при нас е поредното продължение на “Ледена Епоха”, който дори не намира място в топ 20 на box office класацията в САЩ. Филмът на 4-то място “Angry Birds”, също не попада в американската класация на най - касовите филми.

Има огромно разминаване и в продължението на Pixar, а именно “Търсенето на Дори”, който при нас е на 20-та позиция, а в САЩ фигурира под номер 2.

\section{Графика 4}

Български Вох оffice за 2016г. по данни на НФЦ

В левове

ICE AGE: COLLISION COURSE 2D\&3D
ZOOTROPOLIS 2D\&3D

SECRET LIFE OF PETS, THE 2D\&3D

ROGUE ONE: A STAR WARS STORY 3D

ANGRY BIRDS 2D\&3D

JUNGLE BOOK, THE 3D

SUICIDE SQUAD

WARCRAFT 3D

DEADPOOL

GODS OF EGYPT 3D

DOCTOR STRANGE 3D

BATMAN vs. SUPERMAN: DAWN OF JUSTICE 3D

TROLLS 2D\&3D

INFERNO

CAPTAIN AMERICA: CIVIL WAR 3D

DIRTY GRANDPA

KUNG FU PANDA 3 2D\&3D

FANTASTIC BEASTS AND WHERE TO FIND THEM 3D

$11 \mathrm{~A}$

FINDING DORY 2D\&3D

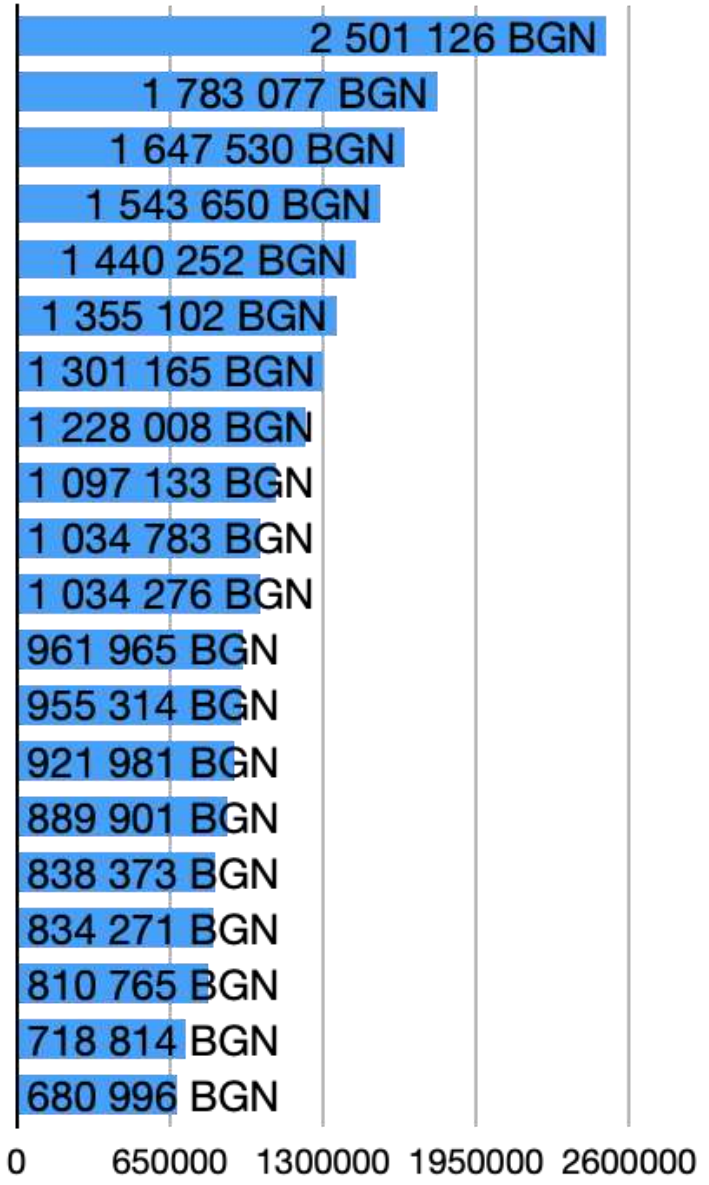

Бележка: Данните са за България НФЦ https://www.nfc.bg/статистика-публичен-регистьр/boxoffice/

Графика 4 всъщност показва топ 20 на най-гледаемите филми на България и на САЩ за 2016г В топ 20 у нас присъства български филм, който се намира на 19-та 
позиция. Той успя да „пребори““Търсенето на Дори”, което е добро постижение за качеството на българското кино и предпочитанията на българския кинозрител.

Освен приликите, съществуват относителни разлики по отношение на предпочитанията на зрителя и те се определят от редица фактори. Един от тях е ниската средна възраст на българския зрител. На база на това твърдение трябва да се отбележи, че цената на билет за 3D е по - висока и именно това може да е една от причините 3D да са най - касови у нас. Представените данни показват предпочитанията на потребителя. За да бъде успешен един филм, трябва да се следят нагласите на зрителите.

\section{Графика 5}

Box office на САЩ за 20162.

\section{USD}

Rogue One: A Star Wars Story

Finding Dory

Captain America: Civil War

The Secret Life of Pets

The Jungle Book (2016)

Deadpool

Zootopia

Batman v Superman: Dawn of Justice

Suicide Squad

Sing

Moana

Fantastic Beasts and Where To Find Them

Doctor Strange

Hidden Figures

Jason Bourne

Star Trek Beyond

X-Men: Apocalypse

Trolls

La La Land

Kung Fu Panda 3

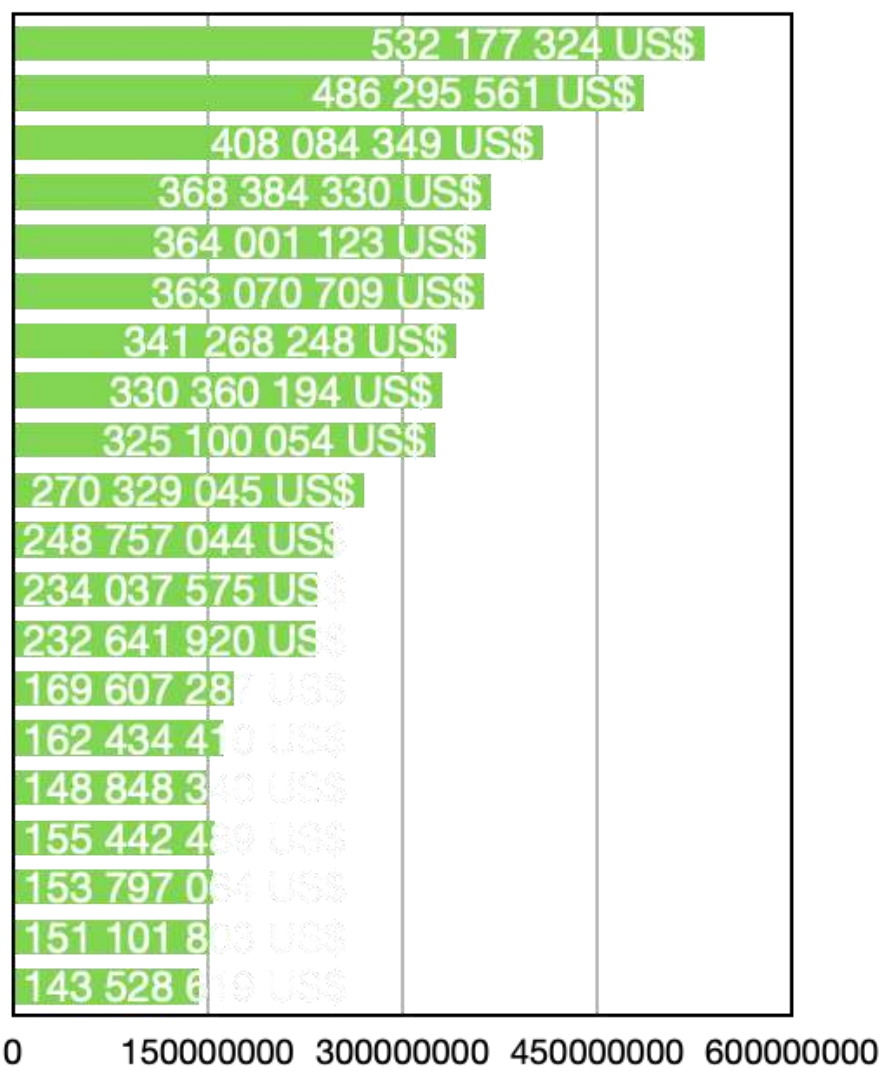

Бележка: Данните са за САЩ от Mojo https://www.boxofficemojo.com

Не може да се създаде продукция само и единствено на база очаквания на потребителя, още повече, че във филмовата индустрия, зрителят формира нагласите си на база продукта, който му се предлага и който търси като аналог на друг такъв, но трябва да се следят основните тенденции. Както вече споменахме само 1 филм е български в топ 20. 
Всъщност и от данните на включената по-рано Графика 3 могат да се проследяти приходите, съответно за представените българските филми през 2016 г. Едва два филма са имали потенциал да си възвърнат вложените финансови средства с общ приход от продажба на билети в размер на 1392548 лв. Те се нареждат на 5-то и 6-то място в класацията за най - касови български филми от 1998 до 2016г. по данни на НФЦ. Ако погледнем класацията само за 2016-та изолирано, бихме казали, че или потребителят няма нужда от български филми, или просто те не са го накарали да отиде в кинозалата. Класацията на най - касовите български филми от 1998 до 2016г. по данни на НФЦ е отразена в Графика 6.

\section{Графика 6}

Вечен Вох оffice в България на български филми към 2016

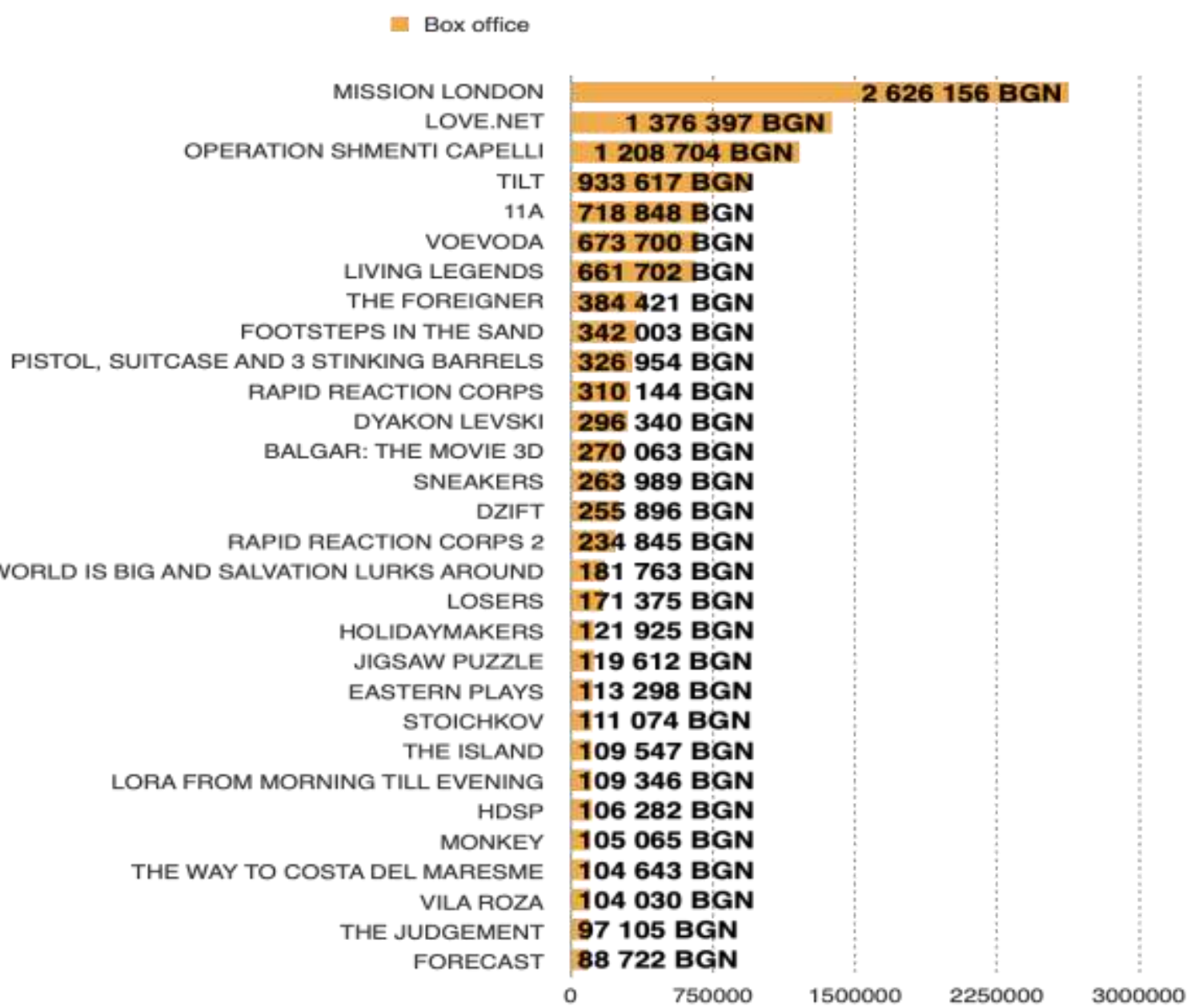

Бележка: Данните са за България НФЦ. https://www.nfc.bg/статистика-публичен-регистьр/boxoffice/ 
Данните сочат, че са няколко филмите, които са успели да минат психологическата граница от 500 хиляди лева приходи. Проблемът на останалите филми от класацията е, че повечето от тях не са акцентирали към потенциалните потребители. Бъъгаринът, който редовно отива на кино е млад човек, той не може да бъде накаран да отиде на кино за филм, който колкото и кинематографски да изглеждадобре е далеч от неговите представи и очаквания. От април 2017 г. до януари 2018 г. излязоха по кината няколко български филма, чийто приходи са отразени в графика 7 .

\section{Графика 7}

Вох оfficе на български филми Април 2017-Януари 2018

\section{Приходи}

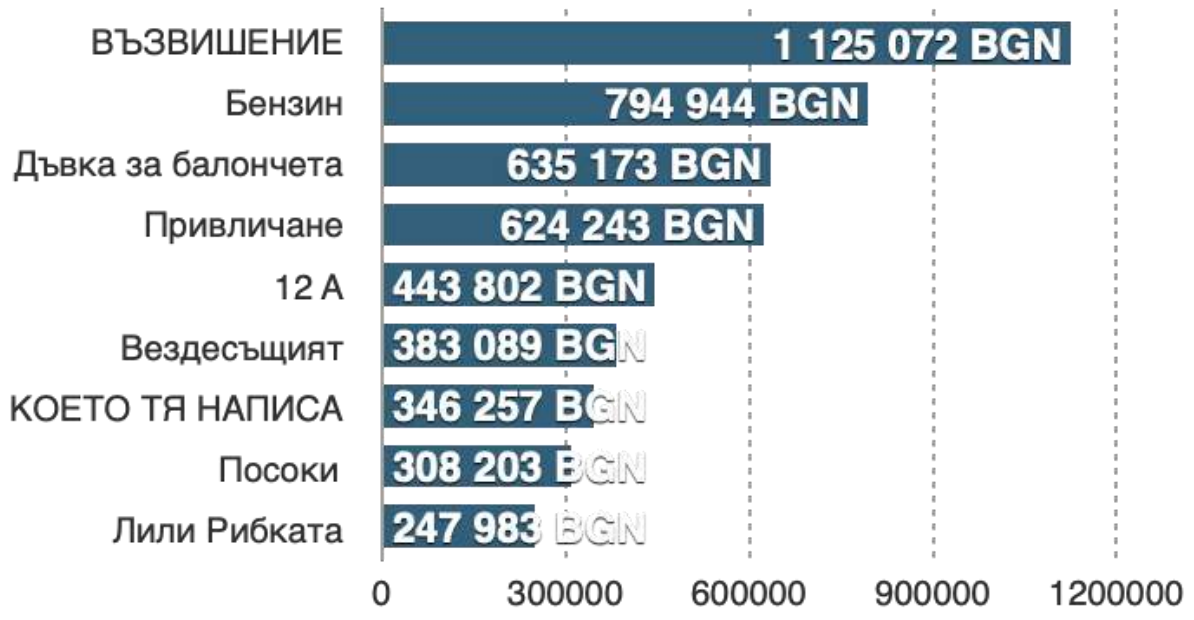

Бележка: Данните са от Box Office класацията на НФЦ за 09-11.03.2018г за България. https://www.nfc.bg/статистика-публичен-регистьр/box-office/ по данни.

Като цяло 5 от 9-те филма са акцентирани към младия потребител, именно затова те имат значително по - висок приходи, от колкото част от филмите, които водиха класацията. От представените данни може да се направи обосновано предположение, че място за българско кино съществува и то е гарантирано в случай, че се създава стойностен аудио-визуален продукт, отговорящ на съществуващите изисквания и стандарти за кинопродукция. Част от гаранциите за успех са добрият маркетинг и успешното пазарно позициониране.

От данните може да се направи извода, че българските филми се представят значително по-слабо от американските продукции.

\section{Продуктово позициониране}


Една от формите за скрито финансиране във филмовата индустрия е продуктовото позициониране. Само по себе си то представлява скрита реклама, която подпомага бюджета на продукцията, но и при коректното внедряване в крайния продукт би могло да подпомогне и сюжетното действие.

Съществуват различни форми за реализация на продуктово позициониране във филмите, а именно:

- Директна визуализация на продукта;

- Визуализация на емблема или лого на продукта;

- Вербално - чрез назоваване марката на продукта в диалозита на героите;

- Визуализация на детайлни елементи на продукта;

- Чрез директо използване от героите на продукта;

- Чрез логото на самия продукт;

- Възможност за включване на сцена в сценария и във филма, заснета изцяло на територията на шоурум, завод, заведение и т.н.

Освен продуктовото позициониране по изброения начин във филмовата продукция има възможност и за:

- Съвместна премиера с акцентиране на продукта;

- Отделна премиера само за продуктие, използвани във филма;

- Организиране на съвместни инициативи - срещи с главните герои , организирани във важно стратегическо място за продукта, съвместни проекти в социалните мрежи;

- Възможност за един от официалните плакати да бъде със снимка на главния герой и продукта;

- Билбордове на филма със снимка на продукта;

- 6 секунди екранно време в 30 секундния телевизиония трейльр на филма;

- 21 секунди време в 90 секундия втори трейлър, предначначен за социалните мрежи;

- Документален филм за участието на продута в процеса на снимане на филма;.

- Изработка на рекламен клип на продукта с участието на главните герои и предоставяне на правата върху него.

В практиката съществуват най- различни комбинации.

\section{Обективни предпоставки в стратегическото продуктово позициониране в киното}

Продуктовото позициониране е насочено към потребностите, желанието и изискването на клиентите. То кореспондира изцяло с похватите на традиционния 
маркетинг. Според Филип Котлър и Гари Армостронг най - същественото понятие в маркетинга е човешките потребности (Amstrong \& Kotler 2013). Потребностите на потребителя реално представлявяват състояние на изпитвано лишение. Включват се ежедневните базови физически потребности на човека, като потребност от храна, облекло, топлина, сигурност и социална нужда от принадлежност и привързаност, знание и себеизразяване. От друга страна е желанието на потребителя, което е повляно от съвременната култура. Всички се нуждаем от храна, но искаме определена марка. Жаждата е съпроводена от желание за конкретна марка бутилирана вода или газирана напитка като Кока-Кола. Желанието се оформя от обществото към което принадлежи потребителя. Например, според Business insider, филмът Iron Man 3 има специална версия за Китай (Acuna, 2013). Премиерата на филма беше в Китай, версията за най големия кино пазар в света, а именно китайския е удължена с 4 минути. В допълнението са включени китайски актьори с цел да се увеличи гледаемостта в Китай. Студиото създател на филма е сключило договор с китайския разпространител DMG entertainment за сътрудничество. В тези 4 минути, освен че са включени китайски актьори е пласирано и продуктово позициониране, което е ексклузивно само и единствено за Китай. Разликите между версията за света и тази за Китай са:

1. Филмът започва с репликата преведена от английски - На какво разчита Iron Man да съживи енергията си, отговорът е “Gu Li Duo”, млечна китайска напитка, произвеждана само за местния пазар.

2. Китайски актьор помага на Iron Man с помощта на китайската медицина

3. Има продуктово позициониране на китайските производители на електроенергия TLC и Zoomilion

4. В някои сцени се появяват щастливи китайски ученици за масовка.

Благодарение на всичко това среднощната премиера Iron Man 3 е генерирала само за 3 часа над 2 милиона долара.

Не е често явление да има различни версии на филм за различни пазари, но както в случая на Iron man 3 има изключения. Случаят с филма за супер героя доказва как различните потребители по света имат различни потребности. Ако дадената млечна напитка е била лансирана за световната версия на филма най - вероятно би било дразнеща реклама за останалата част от света. 
Ако към желанието на потребителите като се добави и покупателната способност, то желанията се превръщат в изисквания. При наличие на желание и възможности (според покупателната способност) потребителят изисква продукти с ползи, които им носят най - голяма стойност и удовлетвореност. Именно заради този факт, продуктовото позициониране е много успешен модел за реклама. Потребителят иска да живее така, както живеят героите в любимия филм или сериал. Зрителят копира модела на поведение, стила на дрехи, типа кола и т.н. Десетки са доказателствата, че даден бранд след успешно продуктово позициониране, увеличава неколкократно своите продажби, както е посочено по-долу в текста.

Една от основните цели на продуктовото позициониране е именно пробуждането на желание. Както се вижда от изложените до сега факти, пазарите са много различни и много трудно може да се позиционира продукт еднакво добре в целия свят. Bond може да пие марка бира в кината в САЩ и Европа, но например в Близкия изток това би били неприемливо и шанса филмът да бъде изтеглен от кината е огромен. Много е важно сегментирането на пазарите. Същевременно с това, следва да се отбележи, чеглобалният маркетинг е изключително важен за големите компании. Днешният свят е много динамичен и може да се каже смален. Бързите комуникации, транспорт и финансови потоци смаляват света до измерението на един телефон или компютър. Продуктовото позициониране е част от глобалния маркетинг. Независимо, че в различните страни има различна покупателна способност, потребителите търсят начини и способи да подражават на своите любимци от големия и малкия екран.Освен сегментирането по принадлежност, маркетинговите компании сегментират и по пол. Според Майкъл Соломон (2011) когато един член от семейството избира сам продукт, това се нарича автономно решение. В традиционните семейства, мъжът носи отговорност при покупка на автомобил, докато изборът за обзавеждане е насочен към жената. Соломон (2011) цитира изследване на „Роупър Старч Уърлдуад“, в което се твърди, че жените в семейството, в частност съпругите, имат думата когато се купуват хранителни продукти, детски играчки, дрехи и лекарства. Благодарение на тези данни продуктовото позициониране в определена сцена във филм ще бъде насочено към жените, докато реклама на техника и автомобили ще бъде насочено към мъжете. Сцените във филм или сериал позволяват подобна сегментация, при условие, че тя бъде договорена с режисьора и реализирана по начин, по който да не дразни зрителя, а да той бъде доволен от 
видяното. По този начин се въздейства на подсъзнателно ниво и рекламираният продукт има шанс да бъде запомнен по-трайно във времето.

Стратегическото позициониране в кинопродукцията е лесен за възприемане похват от зрителя, както на съзнателно, така и на подсъзнателно ниво. Всъщност от наблюденията си сме констатирали, че съществуват различни възможности за интегриране на стратегическото позициониране във филмовия аудио-визуален продукт, а именно:

- Продуктът може да е главен и основен герой в сюжетната линия;

- Продуктът е част от действието във филма и зрителят го възприема като елемент от естествената среда. По този начин, продуктът се асоциира като елемент от представенатадействителност;

- Естествената среда, в която е позициониран продуктьт, преврьща изображението на конкретната марка в потребност;

- Зрителят свързва главния герой във филма с конкретна марка продукт. По този начин се засилва емоционалната връзка между известен актьор и конкретен продукт;

- Продуктът може да е част от общата визия на главния герой. Така се използва асоциативния способ за възприемане на актьора и продукта в едно цялостно и завършено изображение. Изгражда се връзката между харесван герой и неговия правилен избор;

- Продуктовото позициониране не крещи: “купете този продукт, защото е най добрият". Продуктовото позициоиране елегантно показва кой е добрият избор;

- Зрителят живее във втора действителност чрез действителността на филма. Той изживява чувствата не героите, техните емоции, възприема обкръжението им като своя собствена среда. Зрителят се поставя на мястото на определени герои. Вижда в тях себе си. Когато продуктът е част от този свят, той се превръща в реална визуализация. Зрителят го е видял, може би и докоснал. Това е основен елемент от трайността на възприемането на продуктовото позициониране в киното. Зрителят започва да чувства продукта по-близьк, по-познат, по-разпознаваем - обстоятелства, които не могат да бъдат постигнати чрез други рекламни средства;

- Хората обичат да подражават на любимите си актьори. Когато продуктьт е позициониран по начин, който се превръща в част от облика на героя, интересът към актьора е неразривно свързан с интереса към конкретната марка продукт;

- Чрез продуктовото позициониране в киното се налага определен имидж; 
- Продуктовото позициониране формира подсъзнателен избор. Зрителят започва да свиква с деликатното изображение на определена марка продукт. Възприемайки го като неизменен елемент от средата, зрителят започва подсъзнателно да приема, че конкретната марка е достатъчно специална, за да има главна роля във филма. Следователно, да бъде използва такъв продукт е форма на престиж, добър избор и утвърдени позиции;

- Зрителите отиват в киното по собствено желание, те си купуват билет, следователно си купуват и емоция, така те лично са много по-мотивирани да следят детаилно действието. Телевизионните реклами не могат да го постигнат;

- Зрителите в България са потенциални потребители на конкретната марка (директно и индиректно). Тъй като таргет групата на българския зрител в киносалоните е млад човек между 16 и 40 години, идеята е да се сформира потребност към конкретна марка към момента или за в бъдеще. Подобна потребност би рефлектирала върху избора на тяхното семейство при покупка на продукт;

- Участие в продуктово позициониране дава възможност освен за изълчване на готовата продукция в кинозалите, така и за излъчване в национален телевизион ефир.

- В България няколко филма са с голямо количество продуктово позицинорне“Привличане”, “Живи Легенди”, “Нокаут”, “Чужденеца”, “Диви и щастливи”, “Заврьщане”, “love.net", “Бензаин” и др. Филмът с най - много брандово позициноране е “Мислия Лондон” (Стоилова, 2010).

Продуктовото позициониране за българскта реалност може да се използва като алтернативно финансиране на филми. Проблемът е, че спонсорите изискват твърде много реклама, а така зрителят се чувства леко измамен, защото той заплаща билета си за кинофилм, но реално гледа и реклами. Всъщност, най - големият проблем в България за ефективно продуктовото позицинониране е липсата на доверие от страна на рекламодателите. То е породено от липсата на касови, комерсиални български филми с приходи от продажба на билети с еквивалент на американски продукции у нас.

\section{Пазар на продуктово позициониране в САЩ.}

Поради липсата на официални данни за пазара в България, бих искал да анализирам данни за пазара на продуктово позициониране в САЩ.

Според споменатия вече автор Майкъл Соломон (Solomon, 2011) йерархичната класова структура определя достъпа на хората до продукти и услуги. Макар че, според него в 
САЩ няма определена, обективно дефинирана класова система. Факт е, че се подържа обаче стабилна класова структура от гледна точка на разпределение на доходите. Хората, които най - много са податливи към възприемане на скритата реклама, явно и подсъзнателно са гражданите „средна класа“. Жителите от средната класа се опитват да „изглеждат“ по-заможни и масово подражават на героите от любимите си филми. По този начин се опитват „да покажат на света“ своите успехи, дори те да живеят над възможностите си. Точно затова, САЩ е един от най - важните пазари за продуктово позициониране. Самата класова структура, според социолога У. Лойд Уорнър изследвана още през 1941г., се идентифицира в шест социални класи (Lloyd Warner, 1941).

1. Горна горна

2. Долна горна

3. Горна средна

4. Долна средна

5. Горна долна

6. Долна долна

От гледна точна на доходи се дефинират 7 класи в 3 категории-Американци от долната класа, Американци от средната класа и Американци от горната класа. Те са както следва във възходящ ред:

1. „Наистина долна класа““ (7\%) -на социални помощи, видимо бедни, обикновено нямат работа или има т.нар. „мръсна работа“, те са престъпници или скитници.

2. „Долна група хора, но не най - долната“ (9\%) от американците - те работят, но не са на социални помощи, стандартът на живот е точно над границата на бедност, поведението им се оценява като грубо, на тях живота им е виновен за всичко“. И двете подкатегории на долна класа не са в интерес на продуктово позициониране, на тях ще въздейства традиционната реклама, особено когато са включени елементи с големи отстъпки на артикули.

3. Работническа класа (38\%) - първите, които са част от средната класа, те са т.нар. по американски жаргон „сини якички“. Те са със средно заплащане. Те водят т.нар. „начин на живот на работническа класа“" независимо от какъв род са, с какво образование и работа, Те са първата интересна група хора, които се влияят от продуктово позициониране. При тях действа както скритата реклама, така и явната. 
4.Средна класа (32\%) -това са т.нар. работници с „бели якички“ и със „сини якички“ със средно заплащане. Начинът им на живот е по - висок отколкото на „работническата класа“. Те живеят в „по - добрата част на града“, опитват се да правят правилните неща и най - важното за продуктовото позициониране- да подражават на своите любимци от малкия и големия екран. Хората, част от средната класа лесно се влияят на подсъзнателна реклама. Целта им е да покажат на обществото възможно по - голям социален статут. Те карат коли на лизинг, защото в някой филм са я видели, Купуват спортни дрехи на Найк, защото Любимият герой носи подобни продукти. Купуват RayBan, защото Том Круз ги носи в няколко филма и т.н.Или пък устройства на Apple само защото в „онзи сериал“ ги има. При тях традиционната реклама работи много по - слабо отколкото скритата.

5. Горна средна класа (12,5\%) - членовете на тази класа са първите, които са част от горната класа на американците. Жителите, които попадат в горна средна класа са мениджъри, висшисти, професионалисти и т.н. Те членуват във клуб, интересуват се от изкуство и т.н. При тях скритата реклама има ефект, но по - ниськ отколкото в средната класа. Към тях се акцентира рекламата на висок клас коли като (Ауди, Мерцедес, БМВ), модни брандове като Versace, Armani, Cavalli, Dior, Gucci и т.н. За тази група най важното е престижа. При тях традиционната реклама не работи, разчита се само на скритата реклама.

6. Долна горна (1,2\%) - новият социален елит, извлечен от настоящите професионалисти. При тях и традиционната и скритата реклама не работи успешно. Всичко е насочено към доверието в марката и престиж. Те ще си купят Астьн Мартин само защото Јames Bond кара такъв.

7. Горна горна класа $(0,3 \%)$ - най - богатата част от американците. При тях като цяло маркетинг способите трудно работят.

Най - важната класа за продуктово позициониране безспорно са американците от средната класа. Средната класа, освен това, е най - добре развита именно в САЩ. Точно поради тази причина северноамериканският пазар за продуктовото позициониране е най - важният в света.

Данните от Графика 8 разкриват, че продуктовото позициониране бележи ръст в целия свят, но най - големият скок на разходите за продуктово позициониране е именно в 
САЩ. Това доказва, че все повече компании се интересуват и променят маркетинговите си политики по начин, по който да използват скритата реклама ефективно.

\section{Графика 8}

Разходи за продуктово позициониране общо за света, както и за избрани държави през 2012, 2014 и 2019 г. в милиона USD

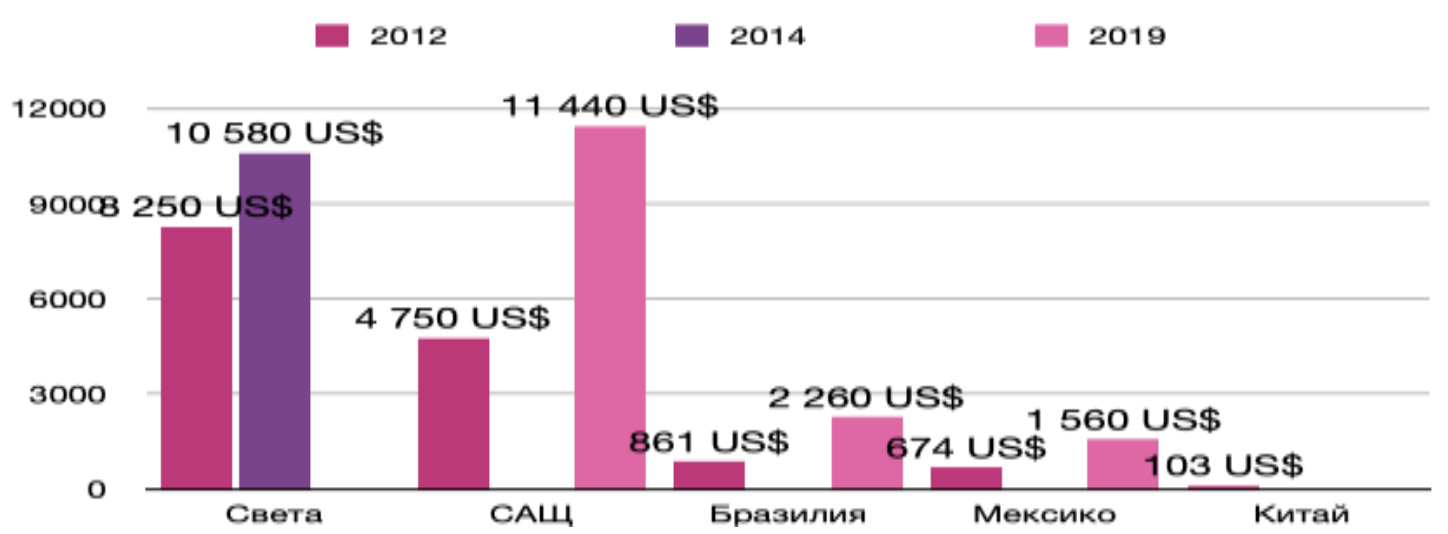

Бележка: По данни от Statista - https://www.statista.com/statistics/261454/global-productplacement-spending/

Данните разкриват, че продуктовото позициониране "работи”, зрителите искат да подражават на своите любими герои от големия и малкия екран.

Чрез кои канали компаниите пласират своите продукти чрез метода на продуктово позициноране за САЩ може да се проследи от Графика 9.

\section{Графика 9}

Разпределение на приходите от продуктово позициониране в Съединените щуати през 2017 2. по медии

\section{Медии}

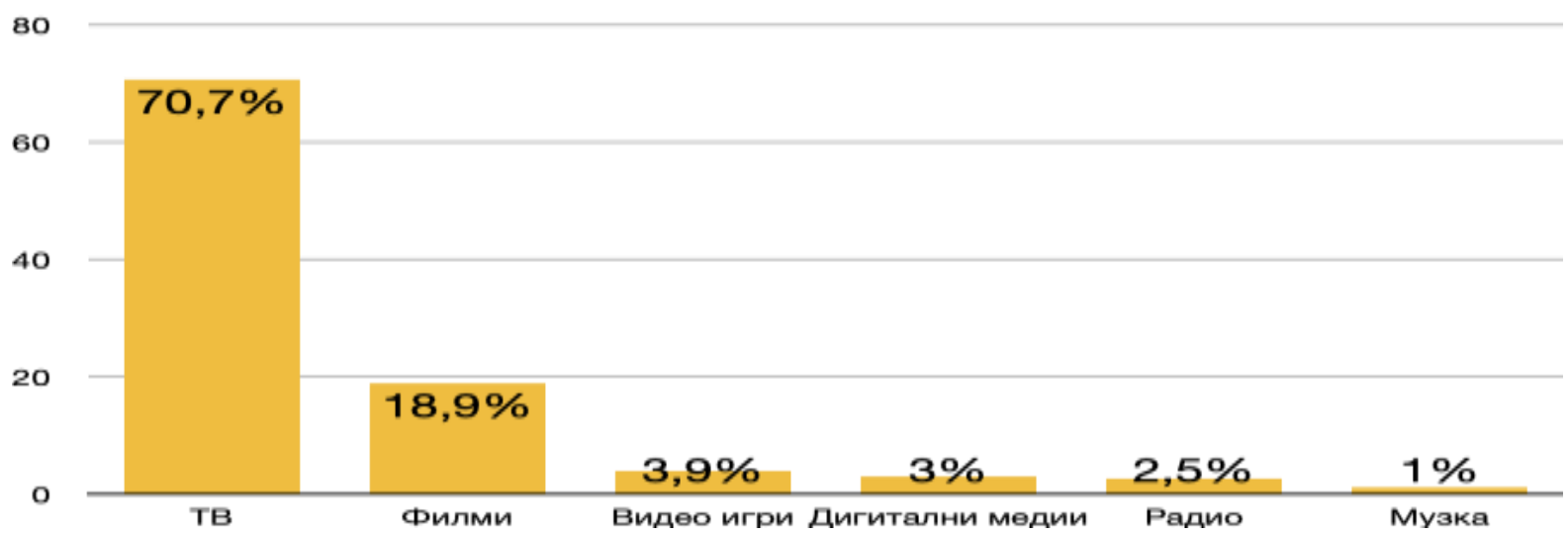

Бележка: Данните са взети от Statista https://www.statista.com/statistics/915189/product-placementrevenue-share-medium/ 
Данните кореспондират с изложената от нас теза, че телевизионната реклама намалява своята ефектвиност и че големите компанни търсят алтернатвни методи за реклама, какъвто е продуктовото позициониране, както във филми, така и в телевизионни предавания и сериали.

Годините преди пандемията бяха изключително силни за големите филмови студия в САЩ. Някои от легендарните поредици като Star Wars ${ }^{1}$, които в миналото се генерирали големи приход смениха своя собственик на авторски права. Буров (2012) описва цялата сделка при придобиването на Lucasfilm от страна на Disney. Тази сделка позволява Star Wars отново да се превърне в „машина за пари“. По подобен начин Disney придоби и легендарното студио $20^{\text {th }}$ Century Fox (Lubin, 2015) Благодарение на придобиването повечето легендарни поредици станаха собственост на Disney като X-man, Индиана Джоунс и Star wars. Интересно е, че Disney е придобил частични права и за Спайдърмен, коетое позволило на Disney да включи човека паяк във филмовата вселена на Marvel (Nikolov, 2009).

Всъщност цялостната политика по придобиване на други филмови компании на Disney започна още през 2005 (La Monica, 2006). Тогава Disney придоби Pixar, като вместо да заплати сумата в кеш преотстъпи голяма част миноритарния далакции на собственика на Pixar Стив Джобс. Друг факт от 2017 показва, че Disney доминира в бокс офиса, това показва колко е била правилна стратегията на Disney (Zapryanov, 2017). Те генерират големи приходи и от мърчандайзинг, така и от продуктови позиционирания, както описания по-долу договор със Самсунг за филма Отмъстителите 2.

Интересен факт е, че пьрвият филм, който е спечелил Оскар за кинематография е филмът “Крила”, който има продуктово позициониране на шоколад Hershey, според IMDB. $^{3}$

Ето някоиобобщени цифри, според Statista и $\mathrm{IMDB}^{4}$ :

САЩ е най-големият и най-бързо развиващият се пазар на платени продукти. Той генерира приходи от 1,5 милиарда долара през 2005 г., 2,9 милиарда долара през 2007 г. и 3,7 милиарда долара през 2008 г.;

$\checkmark$ Данните за 2019 г. показват ръст от над 100\% в САЩ в сравениие с 2009 г.

\footnotetext{
${ }^{1}$ Star Wars: Episode IV - A New Hope. [Movie]. https://www.imdb.com/title/tt0076759/?ref_=nv_sr_srsg_7

${ }^{2}$ Avengers Assemble.[Movie].https://www.imdb.com/title/tt0848228/?ref_=fn_al_tt_1

${ }^{3}$ Wings (1927). [Movie]. https://www.imdb.com/title/tt0018578/?ref_fn_al_tt_2

${ }^{4}$ https://www.imdb.com 
$\checkmark$ Продуктовото позициониране представлява $32 \%$ от общия бюджет за маркетинг, реклама и комуникации;

$\checkmark 60 \%$ от зрителите в залите се отнасят по-положително към марките, които са разпознали във филма;

$\checkmark$ Съществуват данни от Statista, че интересът към рекламата, чрез продуктово позициониране във филми, генерира интерес за 31,2\% от зрителите;

$\checkmark 20 \%$ е увеличението на разпознаваемостта на марката, което може да се очаква от включването на продуктово позициониране във филм;

$\checkmark$ Зрителите, които ходят поне веднъж месечно на кино, ще обърнат по - голямо внимание на продуктовото позициониране във филма;

$\checkmark$ 68\% от позиционирането на продукти продължават 5 секунди или по-малко, но средното време на поставяне на продукт пред камерата е 6,2 секунди;

$\checkmark$ Процентът на продуктовото позициониране, което е визуално и слухово е $3,1 \%$

$\checkmark 71,4 \%$ от продуктовото позициониране в филм са платени, според информация.

Ръстът на продуктовото позициониране във филмите е изключителен през последните 10 години. С темповете на растеж се удвояват няколко години под формата на приходи, индустрията е многомилиардна, която помага на марките да се свържат с някои специфични целеви демографски данни. Когато позиционирането на продукти е интересно, има стойност за потребителя и е в съответствие с това, което се случва в сюжета на филма, тогава много пъти действителното продуктово позициониране дори не се забелязва съзнателно. Когато това се случи, потребителите усещат връзка с дадена марка и я разпознават, без да осъзнават защо са в състояние да я разпознаят. (Bukszpn, 2011).

Някои от най - усшените продуктови позиционирания, предвид рязкото повишаване на продажбите на компаниите, превърнали продуктите си в част от сюжетите на хитови американски кинопродукции в историята на американскито кино, според, $\mathrm{CNBC}^{5} \mathrm{ca}$ :

- Във филма от 1983 г. „Рискован бизнес “، Том Круз носи слънчеви очила RayBan Wayfarer, които станаха емблематични за началото на кариерата му. През 1981 г.

\footnotetext{
${ }^{5} \mathrm{CNBC}$ https://www.cnbc.com/world/?region=world

${ }^{6}$ Risky Business. [Movie]. //www.imdb.com/title/tt0086200/?ref_=nm_flmg_act_46 
Рей-Бан е продала само 18000 бройки и са били пред закриване на линията След филма са продали над 360000 бройки;

- След 60 различни продуктови позиционирания във филмови и телевизионни предавания в периода 81-87 г., Ray-Ban е продала 1, 5 милиона чифта Wayfarers през FY 1986;

- В римейка от 2003 г. на The Italian Job ${ }^{7}$, където се използват Mini Coopers, BMW отбеляза увеличение на продажбите с 22\% спрямо предходната година, въпреки че филмът е имал само умерени нива на успех в бокс офис класациите;

- Том Круз също промотира продуктите на Ray-Ban в Top Gun ${ }^{8}$, като увеличи продажбите на своите сльнчеви очила Aviator с над 40\% след излизането на филма;

- ВМС на САЩ също заявяват, че излизането на филма е довело до редица нови новобранци за техните пилотни програми, като head-up дисплей и др;

- BMW подписва сделка за три филма с MGM, за да позиционира Z3 във филмите, като един от тях е филмът на James Bond GoldenEye. ${ }^{9}$ Автомобильт дори не е бил пуснат на пазара, но продуктовото позициониране е довело до 9000 предварителни поръчки на кола;

- Версията Autobot на Chevy Camaro, която се появи във филма „Трансформърс ${ }^{10 ،, ~ е ~ с ъ з д а л а ~ т о л к о в а ~ м н о г о ~ ш у м ~ с р е д ~ п о т р е б и т е л и т е, ~ ч е ~ д о ~ к р а я ~ н а ~} 2009$ г. са били продадени над 60000 бройки;

- Включването на Etch-A-Sketch в Toy Story ${ }^{11}$ е повишило продажбите с 4500\%. Г-н Картофеният ръководител също отбеляза забележимо увеличение с 800\%;

След позиционирането на продукт в The Apprentice ${ }^{12}$, Pontiac се надява да продаде 1000 превозни средства на марката Solstice за 10 дни. Отнема им само 41 минути.

Ползите от продуктовото позициониране са доста ясни. Когато се позиционира продукт във филм, той получава почти $100 \%$ зрителска аудитория. Ежегодната сума, отделяна от компаниите за продуктово позициониране е милиарди долари, но ако филмът е хит и продуктовото позициониране си възвръща вложените суми.

\section{Позициониране на продуктите през годините}

\footnotetext{
${ }^{7}$ The Italian Job. [Movie]. https://www.imdb.com/title/tt0317740/?ref_=fn_al_tt_1

${ }^{8}$ Top Gun. [Movie]. https://www.imdb.com/title/tt0092099/?ref_=nm_knf_i1

${ }^{9}$ GoldenEye. [Movie]. https://www.imdb.com/title/tt0113189/?ref_=nv_sr_srsg_2

${ }^{10}$ Transformers - Movie https://www.imdb.com/title/tt0418279/?ref_=nv_sr_srsg_2

${ }^{11}$ Toy Story. [Movie]. https://www.imdb.com/title/tt0114709/?ref_=nv_sr_srsg_0

${ }^{12}$ The Apprentice USA [Movie].https://www.imdb.com/title/tt0364782/?ref_=nv_sr_srsg_0 
През 50-те години на миналия век не е било рядкост цели телевизионни предавания или филми да бъдат изградени и сюжетно, и цялостно от една конкретна компания (като Пепси например). Първите продуктови позиционирания, идват от художествената литература. Жул Верн споменава конкретни агенции в романа си „Около света за 80 дни”. Според $\mathrm{CBC}^{13}$ разположенията на телевизионни продукти добавят допълнителни милиарда долара приходи в бюджетите на филми

$\mathrm{B}$,Джурасик Парк“14 една сцена показва магазин, пълен със сувенири в парка, които вече са били налични в магазините в реалния живот. Космическите топки редовно се подиграват с продуктовите позиционирания, героите им дори имат достьп до вече направен филм на VHS като ключов повратен момент на сюжета.

Според данни от Times ${ }^{15}$ :

- 57,5\% от зрителите са разпознали марка при гледане на продуктово позициониране;

- Средният потребител вижда над 3000 марки на ден, което означава, че трябва да се създаде връзка с кинорежисьора чрез смислен сюжет, който да се откроява преди всичко от маркетинговия шум;

- Днешният кинорежисьор става най-притеснен, когато види позииониране на филмови продукти на противоречиви брандове като алкохол, цигари и пистолети.

Повечето аудитории нямат нищо против продуктовото позицциониране, ако то е естествено и вградено към това, което гледат. Например в Dolphin Tale $2^{16}$, служител на USDA критикува директора на аквариума за състоянието на неговите съоръжения. В изявен централен кадър виждаме бирена чаша с лого. Камерата държи към нея в продължение на 3-4 секунди, за да се увери, че се консумира бира Mug. На излизане от мястото на инцидента инспекторите на USDA казват: „Ей. Благодаря за бирата”. Изведнъж неестественото става естествено. Тази еволюция помогна на филмите да могат да компенсират потенциалните загуби, да накарат киноманите да се чувстват добре от

\footnotetext{
${ }^{13} \mathrm{CBC}$ radio https://www.cbc.ca/radio/undertheinfluence/show-me-the-money-the-world-of-product-placement1.3046933

${ }^{14}$ Jurassic Park.[Movie].https://www.imdb.com/title/tt0107290/?ref_=nv_sr_srsg_3

$15 \mathrm{https}: / / \mathrm{www}$.thetimes.co.uk/

${ }^{16}$ Dolphin Tale 2. [Movie]. https://www.imdb.com/title/tt2978462/?ref_=nv_sr_srsg_0
} 
покупките, които правят и да създадат нови потоци от приходи за продукти, които могат да бъдат на ръба на провала.

Добър пример е Хайнекен и филмът за Джеймс Бонд ${ }^{17}$. Според Jason Neuman (2017) има няколко добри примери за пордуктово позициониране. Сумата за продуктово позициониране е около 45 милиона долара, за да може Даниел Крейг да отпие гльтка Хайникен за 3 секунди. Харли Дейвидсьн са платили близо десет милиона за Avengers, за да позиционират новия си мотоциклет Livewire, a Samsung са платили 3-5 милиона за Scarlet да използва таблета им (The best global brands, 2021).

Ежегодно продуктовото позициноране се разраства и вече е с по - голям дял отколкото телевизионната реклама, заради преминаването към модел на стрийминг платформи, за който потребителят си плаща и не гледа реклами.

\section{Потреблението на телевизия}

Потреблението на телевизия се характеризира с големи метаморфози през последното десетилетие, включително и във възрастово отношение. На Графики 10 и 12 са регистрирани съответните промени.

\section{Графика 10}

Потребители на телевизия 2017 за САЩ

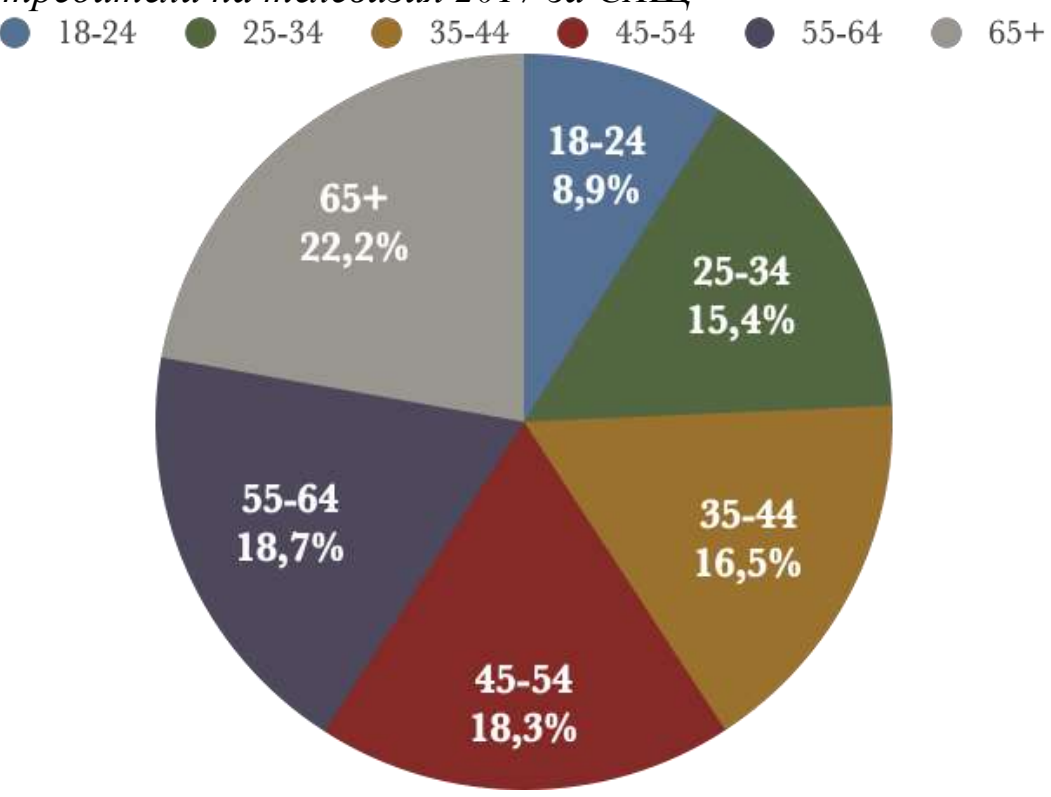

Бележка : по данни от statista https://www.statista.com/statistics/304853/number-ofconnected-tv-users-usal

${ }^{17}$ Spectre. [Movie]. https://www.imdb.com/title/tt2379713/?ref_=nv_sr_srsg_0 


\section{Графика 11}

Потребители на стрийминг 2017 за САЩ

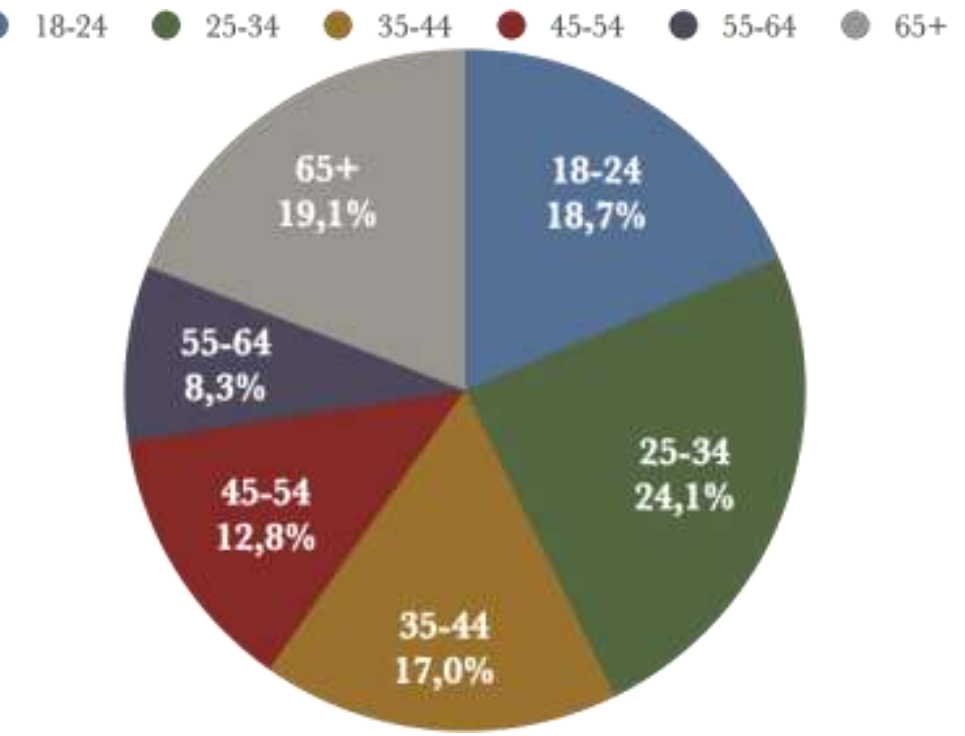

Бележка : по данни от Satista https://www.statista.com/statistics/304853/number-of-connected-tvusers-usa/

Оказва се, че колкото е по-ниска възрастовата група, толкова са по-явни предпочитанията за използване на стриминг платформите. Това е особено отчетливо във възрастовите групи от 18-24 години и от 25-34 години. Данните показват, че близо 60\% от потребителите на стрийминг услуги са характерни за възрастовите групи до 44 години. А основните потребители на телевизията са групите над 45 години. Това показва, че към моемента има място за потребители и от двете групи, но в бъдеще телевизията все повече ще губи зрители, приходи и печалба. Бъдещето ще принадлежи на новия бинзес модел, а именно на стрийминг модела.

На Графика 12 е отразено процентно колко е спадът на 5 годишна база, оцветен в червено и средно годишния спад на потребителите, оцветен в жълто. Графиката отново е по възрастови групи и ясно разкрива тенденцията на две различни поколения, тези които предпочитат традиционата телевизия и тези, които мигрират към стрийминга. Средната дневна гледаемост на потребителя на традиционна телевизия е 3 часа и 55 минути на ден. Спадът между 2015 и 2016 е само 2 минути, а разликата между 2016 и 2017 е 14 минути. Това се дължи на силната експанзия на стрийминг порталите през 2016г. Възрастовата групаот 18-24 години има спад в гледаемостта почти всяко тримесечие. Това се дължи на увеличаването на потреблението на стрийминг порталите, както и традиционните новини вече са изместени от приложения на смартфона. 


\section{Графика 12}

Колко минути средно седмично прекарват в гледане на телевизия или стрийминг потребителите на възраст 18-34 години за САЩ

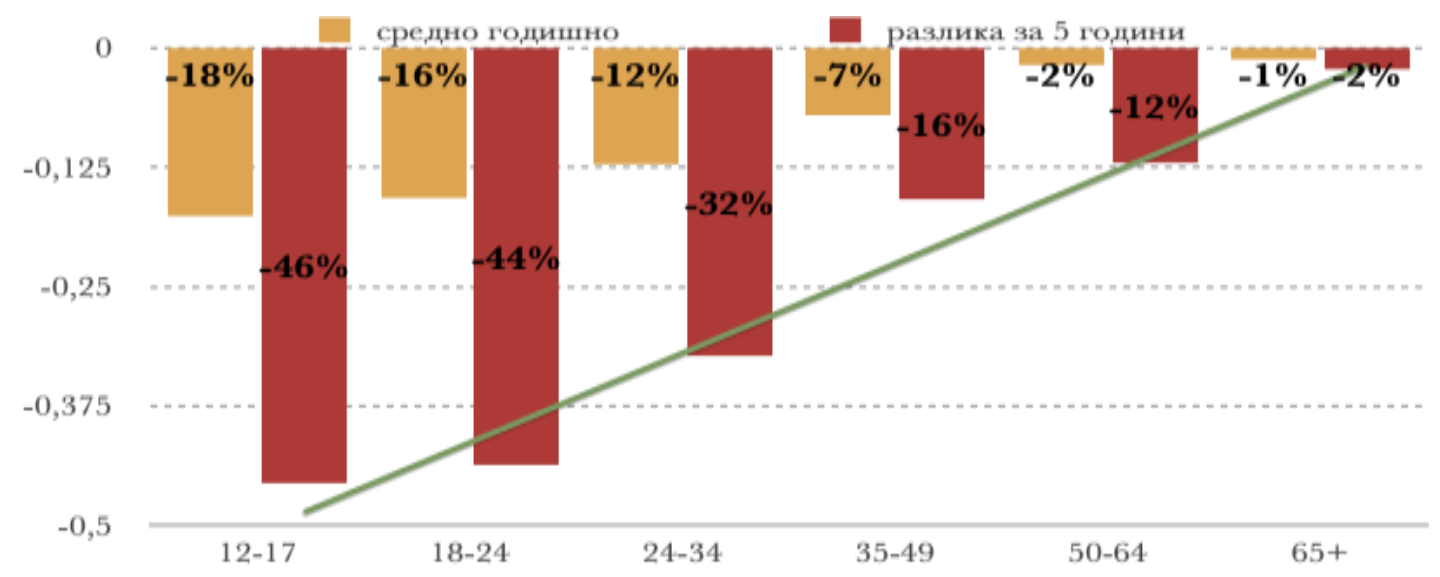

Бележка: по данни от Nielsen https://www.nielsen.com/us/en/insights/article/2018/time-flies-usadults-now-spend-nearly-half-a-day-interacting-with-media/

На графика 12 може да се види и колко минути средно седмично прекарват в гледане на телевизия или стрийминг потребителите на възраст 18-34 години. Всъщност данните са само за телевизия или стрийминг услуги, освен за свързаните устройства към телевизор. Те могат да включват физически носители, стрийминг през устройства като конзоли и игра на видео игри. Колонката за телевизия е традиционата телевизия. Свързаните устройства са за външен носител или конзола. Данните за компютър, таблет и смартфон са само при използването им за гледане на видео от стрийминг портали, като Нетфликс, Хулу, Амазон прайм, HBO GO и други. Те не включват видеа във Фейсбук и т.н. Данните разкриват сравнение между четвърто тримесечие на 2015 и 2016г. Графика 12 показва, че традиционната телевизия доминира за сега, но тя е единствената със спад за посочения период.

Основна причина за спада е, че през първото тримесечие на 2016г. за прьв път $50 \%$ от домакинствата имат активна стрийминг услуга. Според изследването на $\mathrm{TDG}^{18}$ потребителите на възраст 18-34 години, които са едновременно потребители на телевизия и стриймиг услуги ако се наложи да направят избор между двете, биха избрали стрийминг порталите. Към момента Нетфликс има повече платени абонати в сравнение с водещите платени телевиии взети заедно

\footnotetext{
${ }^{18}$ https://thinkdigitalgroup.net/

Postmodernism Problems / Проблеми на постмодерността Vol.11, No. 3, 2021, ISSN: 1314-3700, https://pmpjournal.org https://doi.org/10.46324/PMP2103319
} 
Данните показват, че потребителите на възраст 18-34г. гледат 62\% телевизия от цялото си потребление, но това е 20\% по - ниско, отколкото средно всички потребители. Към момента има потенциал за растеж на потреблението на стрийминг порталите от “умните” устройства за сметка на традиционната телевизия.

Всъщност, бихме могле да обобщим, че благодарение на отлива от традиционната телевизия, според данните и от графики 10,11 и 12, маркетингът започва да търси нови форми за предлагане на своите продукти. Все по - големият ръст на потребление на стрийминг платформи през последните години, принуждава маркетинговите отдели да се обръщат все повече към продуктовото позициониране с цел увеличаване на продажбите. Още повече, че ondemand услугите позволяват при гледане на телевизия да се “прескачат” рекламните блокове.

Пандемията допринесе за по - бърз ръст на стрийминг платформите. Според проучване, проведено през март 2020 г. сред 2200 души на възраст над 18 години в САЩ чрез онлайн допитване с въпрос „Поради Ковид 19 заключването, повече или по.малко сте в състояние да се абонирате за тв или кино стрииминг, се констатира че милениалите са по-склонни да се регистрират за услуги за стрийминг на филми или телевизии, отколкото респондентите в други възрастови групи. 30\% казват, че по-вероятно е да се абонират, в сравнение с едва $15 \%$ от блумерите. Графиката 13 показва, че най - активното население би търсило нов канал за потребление на филми.

\section{Графика 13}

Дял на възрастните, кочто са по-склонни да се абонират за нова услуга за стрийминг на филми поради избухването на коронавирус в САЩ от март 2020 г.

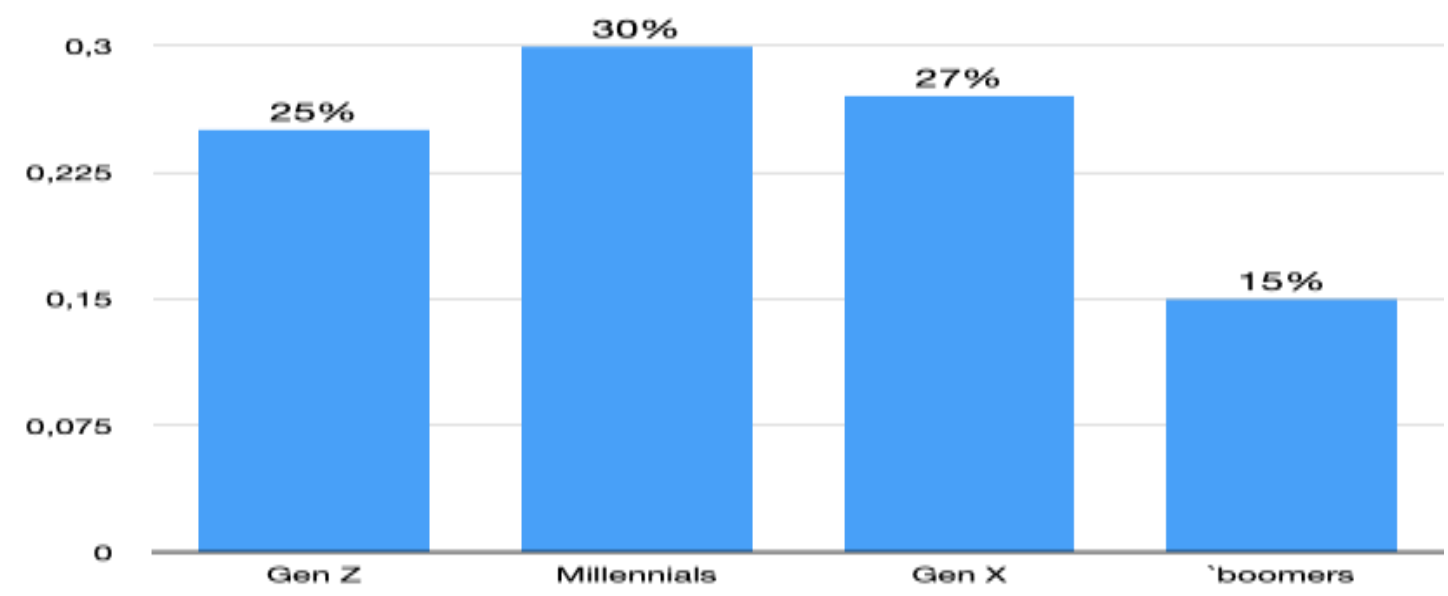

Бележка: Данните са от Statista https://www.statista.com/statistics/1104003/svod-subscriptionscoronavirus-by-age-us/ 
Повечето хора, потребители на кино имат чисто емоционална и сантиментална привързаност към киното. Това би значило, че когато кината бъдат отворени, безопасни са и имат нови заглавия, потребителите биха се върнали в залите, което всички се надяваме да стане в началото на 2022г.

Като цяло продуктовото позициониране нараства всяка година. То помага на продуцентите да развият правилно бюджетите си и да намалят рисковете за студията си. Зрителят не се дразни само ако продуктовото позициониране е добре включено към сюжета. Скритата реклама има своите недостатьци, но ако е реализирана релевантно, тя става може би най - успешният маркетингов продукт.

\section{Използвана литература}

Acuna, K. (2013. May.02).The biggest differences in China's version of 'Iron Man 3'. https://www.businessinsider.com/chinas-version-of-iron-man-3-2013-5

Armostrong, D., Kotler, F. (2013). Vuvedenie v marketinga [Marketing : an introduction] Sofia.

Bukszpn, D., (2011. June. 03). 10 big successes in product placement. https://www.cnbc.com/2011/06/03/10-Big-Successes-in-Product-Placement.html

Burov, F. (2012. Oktober, 31) . Disney kupi "Mezhduzvezdni voyni" za 4 mlrd. Dolara [Disney bought Star Wars for \$ 4 billion]. Kapital https://www.capital.bg/biznes/kompanii/2012/10/31/1937029_disney_kupi_mejduzve zdni_voini_za_4_mlrd_dolara/

CBC radio (2015, August, 04) Show me the money: The World of Product Placement https://www.cbc.ca/radio/undertheinfluence/show-me-the-money-the-world-ofproduct-placement-1.3046933

La Monica, P.R. (2006, January 25). Disney buys Pixar. House of mouse is teaming up with Pixar in a $\$ 7.4$ billion deal. Steve Jobs to become board member at Disney. https://money.cnn.com/2006/01/24/news/companies/disney_pixar_deal/

Lloyd Warner,W and Lunt, P. S. (1941). The social life of a modern community. New Haven, Yale University Press.

Lubin, G. (2015, April 6). It's astonishing how far Disney is going to bury the X-Men. http://www.businessinsider.com/its-astonishing-how-far-disney-is-going-to-bury-theX-men-2015-4 
Neuman, J. (2017). Movie \& film product placement - what's the cost and what's the value? https://jasonneuman.medium.com/movie-film-product-placement-whats-the-cost-andwhat-s-the-value-14082f2df464

Nikolov, K. (2009, September). Miki Maus shte komandva choveka-payak. Disney kupi legendarniyat sazdatel na komiksi Marvel Entertainment [Mickey Mouse will command Spider-Man. Disney has bought legendary comic book creator Marvel Entertainment]. https://www.capital.bg/biznes/kompanii/2009/09/04/779390_miki_maus_shte_koman dva_choveka-paiak/

Solomon, M. (2011). Potrebitelskoto povedenie [Consumer Behavior].Sofia.

Stoilova, Z. (2010, April 23). Misia reklama [Mission Advertising]. Kapital. https://www.capital.bg/biznes/kompanii/2010/04/23/891689_misiia_reklama/

Rosenblatt K. (2021, Oktober, 04) Netflix's 'squid game' is a sensation. Here's why it's so popular. https://www.nbcnews.com/pop-culture/pop-culture-news/netflix-s-squidgame-sensation-here-s-why-it-s-n1280646

The best global brands 2021 report. (n.d). Interbrand Thimking. http://www.brandchannel.com/2014/11/14/samsung-harley-davidson-go-all-out-forproduct-placement-in-avengers-2

Zapryanov, J (2017, May 12). Bezkraynata vselena na Marvel [The endless universe of Marvel]. Kapital. https://www.capital.bg/biznes/kompanii/2017/05/12/2969200_bezkrainata_vselena_n a_marvel/ 